\title{
Protease-deficient Mutants of Pseudomonas aeruginosa: Pleiotropic Changes in Activity of Other Extracellular Enzymes
}

\author{
By BENGT WRETLIND \\ Department of Clinical Microbiology, Karolinska Hospital, \\ S-I040 I Stockholm, Sweden \\ AND LENNART SJÖBERG AND TORKEL WADSTRÖM* \\ Department of Bacteriology, National Bacteriological Laboratory, \\ S-I052I Stockholm, Sweden
}

(Received 29 June 1977)

Mutants of Pseudomonas aeruginosa strain PAKs-I which are defective in the formation of extracellular protease activity have been characterized. The mutants produced between approximately I and $25 \%$ of the protease activity of the wild type and no strains completely lacking extracellular protease were found, even after repeated mutagen treatment. Most mutants also had changed activities of extracellular staphylolytic enzyme, lipase and lecithinase. Four of 13 mutants were unable to release alkaline phosphatase and staphylolytic enzyme into the medium in contrast to the wild type. Serotype, phage type and biochemical reactions were essentially unchanged. The results indicate that some of the mutations affected the cell envelope structure or function leading to decreased ability to release extracellular proteins, and that other mutations possibly affected a common regulatory mechanism for extracellular enzymes.

\section{INTRODUCTION}

Pseudomonas aeruginosa produces several extracellular enzymes and toxins. Some of these factors may play a role in the pathogenesis of Pseudomonas infections (Liu, 1974; Wretlind et al., I973). Most strains produce three extracellular proteases (Morihara, 1964). One of these enzymes (protease II) possessing elastase activity, is dermonecrotic, corneadamaging, and probably responsible for the destruction of the arterial elastic lamina in patients with Pseudomonas bacteraemia (Kawaharajo et al., 1975; Kreger \& Griffin, 1974; Mull \& Callahan, 1965).

Although many reports have been published on the genetics of Pseudomonas (Holloway, 1975), we do not know of any such studies on extracellular enzymes and toxins. This study was undertaken to examine the properties of protease-deficient mutants of $P$. aeruginosa with respect to formation of other extracellular enzymes, biochemical reactions and virulence for mice. This report describes some properties of the isolated mutants. The results of the animal experiments will be reported elsewhere.

\section{METHODS}

Bacterial strain. Pseudomonas aeruginosa strain PAKs-I was isolated in 1970 from a urine specimen at the Karolinska Hospital. The strain was identified as $\boldsymbol{P}$. aeruginosa as described previously (Wretlind $e$ t al., 1973). It was selected for this study becaüse it was the best producer of extracellular elastase among 30 strains

* Present address: Department of Bacteriology, Royal Veterinary College, Biomedicum, Box 583, S-75I23 Uppsala, Sweden. 
tested. The strain produced three proteases in minimal medium supplemented with yeast extract and glucose as described below. These probably corresponded to the proteases characterized by Morihara (1964) (Wretlind \& Wadström, 1977). It also produced extracellular staphylolytic enzyme, lipase, lecithinase, haemolysin and deoxyribonuclease (Burke \& Pattee, 1967; Wretlind et al., I973).

Isolation of mutants. Mutants were obtained according to the procedure described by Meynell \& Meynell (1970) using ethyl methanesulphonate as mutagen. The bacteria were plated on brain-heart infusion (BHI) agar plates containing $15 \%$ (v/v) sterile skimmed milk (Wretlind et al., 1973) to give approximately 100 colonies per plate. The plates were inspected after 14 to $\mathrm{I} 6 \mathrm{~h}$. The wild-type strain gave clear zones around single colonies and the mutants gave a faint white precipitate or no zone at all. Elimination of plasmid DNA (curing) was attempted using acriflavin and ultraviolet light, sodium dodecyl sulphate and growth at $44^{\circ} \mathrm{C}$ according to Maliwan et al. (1974).

Characterization of mutants. The following biochemical reactions were performed to exclude the possibility that the strains isolated were contaminants and to reveal any metabolic changes: $\mathrm{O} / \mathrm{F}$ test for glucose; ability to ferment xylose, mannitol, fructose, arabinose, mannose, galactose, melibiose, ribose and cellobiose; determination of arginine dihydrolase, lysine decarboxylase, ornithine decarboxylase and oxidase activities. The reactions were read after 1,2 and 7 days. The strains were also tested for their ability to grow on minimal medium agar (Davis \& Mingioli, 1950) with glucose (10 $\mathrm{mM}$ ) as carbon source, endo agar, cetrimide agar, phenyl ethanol agar with $5 \%$ (v/v) horse blood and deoxycholate/citrate agar (Vera \& Dumoff, 1974).

Phage typing and serotyping. Phage typing was done with a standard set of $22 P$. aeruginosa bacteriophages as described by Sjöberg \& Lindberg (1968). Serotyping was by agglutination and haemagglutination using twofold dilutions of the antisera by the system of Habs (1957).

Agar plate methods. The ability to produce various extracellular enzymes was determined on different agar plates. Positive reactions were defined as zones of activity of more than $2 \mathrm{~mm}$ around the streaks. Protease was assayed on BHI agar plates containing $15 \%(\mathrm{v} / \mathrm{v})$ skimmed milk, elastase on elastin agar plates, phospholipase on agar plates containing egg lecithin $\left(5 \mathrm{~g}^{-1}\right)$, staphylolytic enzyme on agar plates containing heat-killed cells of Staphylococcus aureus strain Copenhagen, deoxyribonuclease on DNAase test agar, lipase on tributyrin agar, and haemolysin on Columbia agar containing $5 \%(\mathrm{v} / \mathrm{v})$ horse blood (Wretlind et al., 1973). The reactions were read after 24 and $48 \mathrm{~h}$ incubation at $37^{\circ} \mathrm{C}$. The elastin, lecithin and staphylococcal agar plates were incubated for 5 more days at room temperature.

Cultivation techniques. For quantitative determinations of extracellular enzymes, the strains were cultivated in shaking flasks and fermenters at $37{ }^{\circ} \mathrm{C}$. Four media were used: (i) minimal medium of Davis \& Mingioli (1950) supplemented with yeast extract $\left(2 \mathrm{~g}^{-1}\right)$, glucose (25 mM) and $\mathrm{CaCl}_{2}$ (I mM) (MYG); (ii) MYG medium supplemented with Casamino acids ( $\log 1^{-1}$ ) (MCYG); (iii) minimal medium supplemented with tryptone (5 $\left.\mathrm{g} \mathrm{l}^{-1}\right)$, yeast extract $\left(2 \cdot 5 \mathrm{~g} \mathrm{l}^{-1}\right)$ and glucose ( $5 \mathrm{mM}$ ) (MTYG); and (iv) phosphate-deficient medium (Torriani, 1968). Cultures in I 1 Erlenmeyer flasks containing $100 \mathrm{ml}$ medium were incubated on a rotary shaker (I40 rev. $\mathrm{min}^{-1}$ ) for $8 \mathrm{~h}$ (MCYG medium) or $\mathrm{I} 6 \mathrm{~h}$ (MYG and MTYG media). With phosphatedeficient medium, cultures were incubated in shaking $200 \mathrm{ml}$ flasks containing $20 \mathrm{ml}$ medium for $16 \mathrm{~h}$. Bacterial growth was estimated from the culture absorbance at $650 \mathrm{~nm} ; E_{650 \mathrm{~mm}}^{10 \mathrm{~mm}}=\mathrm{r} \cdot 0$ corresponded to a bacterial dry weight of $0.6 \mathrm{~g} \mathrm{l}^{-1}$. The strains were also cultivated in MCYG medium at constant $\mathrm{pH}\left(7^{\circ} 4\right)$ in a stirred fermenter with a working volume of I 1 (Biotec FL IOI, Biotec, Stockholm, Sweden). The air flow rate was $11 \mathrm{~min}^{-1}$ and the impeller speed $500 \mathrm{rev} . \mathrm{min}^{-1}$. The inoculum was prepared by centrifuging (4000 $\mathrm{g}$, $10 \mathrm{~min}) 200 \mathrm{ml}$ of an overnight culture in the same medium and resuspending the bacteria in fresh medium. Samples for bacterial dry weight and enzyme assays were taken every hour (Arvidson, Holme \& Wadström, 197I). To estimate the amount of cell-bound protease and staphylolytic enzyme the strains were cultivated in flasks in MCYG medium overnight. A sample of the culture was centrifuged (4000 $\mathrm{g}$, Io min), the cell pellet was washed once with sodium phosphate-buffered saline (PBS), resuspended in PBS and disintegrated in $10 \mathrm{ml}$ portions by ultrasonic treatment ( $300 \mathrm{~W}$, I min; Labsonic 1510 , Braun, Melsungen, Germany).

Enzyme assays. Protease activity was determined according to the method of Kunitz (1946/1947) using heat-denaturated casein ( $\mathrm{IO}^{-1} \mathrm{l}^{-1}$ ) as substrate. The extent of proteolysis was determined by reading the $E_{280 \mathrm{~mm}}^{10 \mathrm{~mm}}$ of perchloric acid-soluble peptides. One unit of protease activity caused an increase in $E_{280 \mathrm{~nm}}^{10 \mathrm{~mm}} \mathrm{I} \cdot \mathrm{O}$ in 30 min at $37^{\circ} \mathrm{C}$.

Staphylolytic activity was determined by a modification of the method described by Burke \& Pattee (1967), as the rate of lysis of heat-killed cells of $S$. aureus strain Copenhagen at $37^{\circ} \mathrm{C}$. Lyophilized whole staphylococci were suspended in Io mM-sodium phosphate buffer $\mathrm{pH} 8.5$, boiled for 10 min and diluted to $E_{650 \mathrm{~nm}}^{10 \mathrm{~mm}}=0.8$. The sample $(0.1 \mathrm{ml})$ was added to $\mathrm{I} \cdot 9 \mathrm{ml}$ staphylococcal suspension and the mixture was rapidly transferred to a cuvette in a recording spectrophotometer (Zeiss PMQ2) fitted with a thermostat. One unit of enzyme activity caused a decrease in $E_{650}^{10 \mathrm{~mm}}$ of 1.0 in 1 min.

Lipase activity was determined by a modification of the method described by Staeudinger et al. (1973), using p-nitrophenyl caprylate as substrate at a concentration of $7 \mathrm{~mm}$. A stock solution of the substrate was prepared in dimethyl sulphoxide; 10 $\mu \mathrm{l}$ of the stock solution was mixed with $1.0 \mathrm{ml} \mathrm{O} \cdot \mathrm{I}$ M-sodium phosphate 
buffer $\mathrm{pH} 7 \cdot 4$. The sample $(0 \cdot 1 \mathrm{ml})$ was added, and the mixture was transferred to a cuvette in a recording spectrophotometer (Zeiss PMQ2). The linear increase in $E_{410 \mathrm{~mm}}^{10 \mathrm{~mm}}$ was measured; one unit of enzyme activity hydrolysed I $\mu \mathrm{mol}$ of substrate in I min at $25^{\circ} \mathrm{C}$.

Alkaline phosphatase was assayed according to Torriani (1968) using $p$-nitrophenyl phosphate as the substrate. The assay was performed on culture supernatants and whole cells from cultures in phosphatedeficient medium. The pellet was suspended in $\mathrm{I} \cdot 2 \mathrm{M}$-Tris/ $\mathrm{HCl} \mathrm{pH} 8 \cdot 2$, and this suspension was used for the assay. The fraction of cell-bound activity was calculated for each mutant.

Determination of antibiotic sensitivity and generation time. Sensitivity to ampicillin, carbenicillin, cephalothin, erythromycin, tetracycline, chloramphenicol, streptomycin, gentamicin, actinomycin D and colistin was determined by the quantitative disc diffusion method recommended by Ericsson \& Sherris (I97I). Antibiotic sensitivity was also determined using the Autobac I system (Pfizer Diagnostics, Groton, Connecticut, U.S.A.) described by Praglin et al. (1975). The equipment was kindly supplied by AB Biodisk, Solna, Sweden. The generation time of the mutants was calculated from repeated determinations of the growth index in the Autobac I using a programmable computer (Monroe 1860; Litton, Orange, New Jersey, U.S.A.) (B. Wretlind and K. Karlsson, unpublished data). The growth index was defined according to Praglin et al. (1975).

Zymogram technique for identification of different proteases in culture supernatants. Pseudomonas aeruginosa strain PAKS-I produced three extracellular proteases which could be separated by isoelectric focusing: the isoelectric points were 8.5 (protease I), 6.6 (protease II, elastase) and 4.5 (protease III). The wild-type strain and the mutants were cultivated in MYG medium overnight. Protease II and protease III were separated from culture supernatants by agarose gel electrophoresis ( $0.75 \%$ agarose) at $\mathrm{pH} 8.6$ in $0.024 \mathrm{M}$-sodium barbital buffer. The electrophoresis was run at $8 \mathrm{~V} \mathrm{~cm}^{-1}$ for $30 \mathrm{~min}$. An overlayer containing agarose ( $10 \mathrm{~g}^{-1}$ ), casein ( $\left.15 \mathrm{~g}^{-1}\right), \mathrm{KH}_{2} \mathrm{PO}_{4}(2 \mathrm{mM})$ and $\mathrm{CaCl}_{2}$ ( $\left.\mathrm{ImM}\right)$ at $\mathrm{pH} 7 \cdot 4$ was then applied. Protease activity resulted in opaque precipitates after I to $4 \mathrm{~h}$ incubation at $37^{\circ} \mathrm{C}$. Protease I was not detected under these conditions. Partially purified protease II and III were run as controls. Supernatants with low protease activities were concentrated 10 to $50 \times$ using a Minicon BI5 microconcentrator (Amicon, Lexington, Massachusetts, U.S.A.) so that activities of 20 to $40 \mathrm{u}$. $\mathrm{ml}^{-1}$ were obtained.

Chemicals and reagents. Yeast extract, Casamino acids, Tryptone, Bacto-peptone, brain heart infusion and phenyl ethanol agar were obtained from Difco; DNAase test agar and Columbia agar from BBL; endo agar and deoxycholate/citrate agar from Oxoid; antibiotic sensitivity discs, PDM antibiotic sensitivity medium and Eugonic broth from AB Biodisk, Solna, Sweden; agarose (Indubiose A37) from L'Industrie Biologique Française, Gennevilliers. France; casein from Nutritional Biochemicals, Cleveland, Ohio, U.S.A.; ethyl methanesulphonate, $p$-nitrophenyl phosphate, $p$-nitrophenyl caprylate, and Tris [tris(hydroxymethyl)aminomethane] from Sigma; dimethyl sulphoxide from Mallinckrodt, St Louis, Missouri, U.S.A.; and other chemicals (analytical grade) from Merck.

\section{RESULTS \\ Isolation of mutants}

Protease-deficient mutants were obtained at a frequency of approximately $\mathrm{IO}^{-4}$ after treatment of strain PAKS-I with ethyl methanesulphonate. In total, Io mutants were isolated, designated PAKS-II, PAKS-I4 to PAKS-20, PAKS-22, and PAKS-23. One spontaneous mutant (PAKS-IO) was isolated from an agar plate stored for a few weeks at $4{ }^{\circ} \mathrm{C}$. Further attempts to isolate spontaneous mutants were unsuccessful. One mutant (PAKS-3I), selected for loss of extracellular lecithinase on lecithin agar plates, shared several properties with the protease mutants and is described with these strains. PAKS-4I was a chloramphenicol-resistant mutant that was protease-deficient; the chloramphenicol resistance was unstable but the strain retained its protease deficiency. Treatment of strain PAKS-I with acriflavin and ultraviolet light, with sodium dodecyl sulphate and by growth at $44{ }^{\circ} \mathrm{C}$ did not produce proteasedeficient progeny.

\section{Characterization of protease mutants}

Protease-deficient mutants gave a faint precipitate or no zone at all round isolated colonies after $\mathrm{I} 4$ to $\mathrm{I} 6 \mathrm{~h}$ incubation on agar plates containing skimmed milk. However, all mutants produced a clear zone of proteolysis around areas of confluent growth indicating a low residual protease activity. The mutants were cultivated in different media and the formation of extracellular protease, lipase and staphylolytic enzyme was compared with the wild-type strain. DNAase, haemolysin and lecithinase were estimated using agar plate methods, since 
B. WRETLIND, L. SJÖBERG AND T. WADSTRÖM

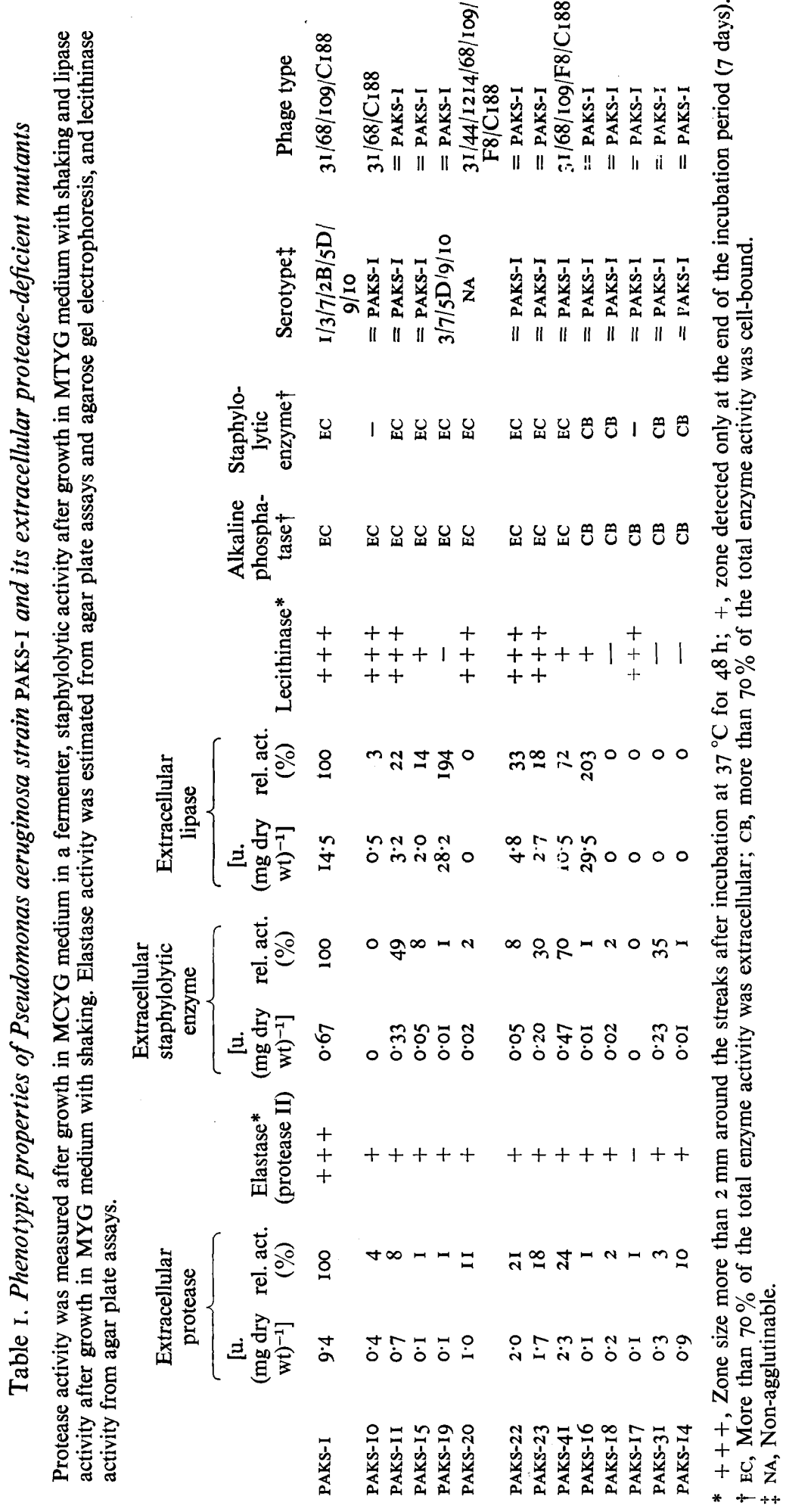


these products were not formed in the broth media in detectable amounts (Liu, 1964). The formation of DNAase and haemolysin was not affected in the mutants.

The results of the cultivation experiments are shown in Table I. After 6 to $8 \mathrm{~h}$ growth, the dry weight of PAKS-I in the fermenter was $\mathrm{I} \cdot 6 \mathrm{~g} \mathrm{l}^{-1}$ and all but two mutants had dry weights in the range 0.95 to $2.4 \mathrm{~g}^{-1}$. Two mutants gave higher yields, probably due to the formation of cell-bound slime under these conditions. However, growth was similar to that of the wild-type strain in three different media as judged by the $E_{650 \mathrm{~mm}}^{10 \mathrm{~mm}}$ of the culture when these strains were cultivated in shaking flasks. The protease activity of the mutants varied from approximately I to $25 \%$ of the activity of the wild-type strain in flasks and fermenters. The values varied depending on experimental conditions, but mutants with a low production of protease never produced more than $10 \%$ of the activity of the wild type, and mutants with a comparatively high production of protease retained that property in different media. All of the mutants except one (PAKs-I7) produced protease II (elastase) as judged by the results from the elastin agar plates and agarose gel electrophoresis. Most mutants also had decreased activities of other extracellular enzymes. However, there seemed to be no correlation between the extracellular activities of staphylolytic enzyme, lipase and lecithinase. Determination of protease and staphylolytic activity in disintegrated cells revealed a significant cell-bound protease activity $\left[5 \mathrm{u} .(\mathrm{mg} \mathrm{dry} \mathrm{wt})^{-1}\right]$ in the cell envelope or cytoplasm of strain PAKS-20 in contrast to PAKS-I and the other mutants which had less than I $u$. (mg dry wt) ${ }^{-1}$. With strains PAKS-I4, PAKS-16, PAKS-I 8 and PAKS-3I more than $70 \%$ of the total staphylolytic activity was cell-bound. The total staphylolytic activity of these strains was approximately equal to that of PAKS-I (Table I).

All mutants were able to grow in phosphate-deficient medium and to produce alkaline phosphatase in approximately the same amounts. The wild type and eight of the mutants released the phosphatase and less than $30 \%$ of the total activity remained cell-bound. In five mutants more than $70 \%$ of the total activity was cell-bound and they were apparently unable to release the enzyme.

Two mutants, PAKS-18 and PAKS-I9, were treated with ethyl methanesulphonate and plated on agar containing skimmed milk in an attempt to detect mutants with complete loss of extracellular protease activity. No such mutants were found among a total of 50000 screened colonies, but a few mutants were found which seemed to produce less protease than PAKS-I 8 and PAKS-I9. These mutants were not characterized further.

Strain PAKS-I and all its mutants showed the same biochemical reactions, typical of strains of $\boldsymbol{P}$. aeruginosa (Hugh \& Gilardi, 1974). All mutants were able to grow on plates containing minimal medium agar, endo agar, deoxycholate/citrate agar, cetrimide agar and phenyl ethanol agar.

Serotyping according to Habs (1957) showed that the wild type was agglutinated by seven antisera but gave the strongest agglutination by antiserum against serotype 9 . This pattern was retained by all but two mutants: PAKS-I 9 which was agglutinated by five antisera, and PAKS-20 which was non-agglutinable. The latter strain also had an altered phage type.

Antibiotic sensitivity testing by the disc diffusion method showed that mutant PAKs-I I was more sensitive to some antibiotics than the wild type. The zone diameter around a streptomycin disc $(30 \mu \mathrm{g}$ ) was $28 \mathrm{~mm}$ (wild type $16 \mathrm{~mm}$ ), around gentamicin $(30 \mu \mathrm{g}$ ) $38 \mathrm{~mm}$ (wild type $22 \mathrm{~mm}$ ) and around colistin $(30 \mu \mathrm{g}) 25 \mathrm{~mm}$ (wild type $19 \mathrm{~mm}$ ). Sensitivity to ampicillin, carbenicillin, tetracycline and chloramphenicol was not significantly changed. Strain PAKS-I5 was more resistant to carbenicillin than the wild type (zone diameter around a $100 \mu \mathrm{g}$ carbenicillin disc $12 \mathrm{~mm}$, wild type $16 \mathrm{~mm}$ ). Antibiotic sensitivity testing with

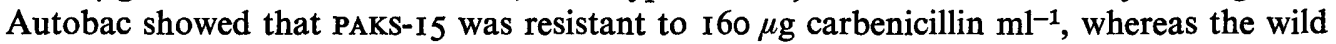
type was sensitive. Strains PAKS-I9 and PAKS-20 were sensitive to $160 \mu \mathrm{g}$ ampicillin $\mathrm{ml}^{-1}$ in the Autobac system (wild type resistant). No other significant changes were observed. The generation times of the mutants were similar to that of the wild type $(33 \mathrm{~min})$, except for three strains: PAKS-I9 (4I min), PAKS-22 (49 min) and PAKS-23 (42 min). 


\section{DISCUSSION}

The phenotypic properties of protease deficient mutants of $P$. aeruginosa are shown in Table I. All strains had extracellular protease activity, and the positive reactions on elastin agar plates and agarose gel electrophoresis revealed that at least a part of the protease activity was due to protease II (elastase). Another source of extracellular protease activity might have been leakage of intracellular proteases from strains lacking the common extracellular proteases as has been described for mutants of Arthrobacter (Rudin \& v. Hofsten, 1974) but we have no evidence for this mechanism among the mutants described here. We have not been able to produce mutants completely lacking extracellular protease even after repeated treatment with mutagen. All mutants show pleiotropic changes of activities of other extracellular proteins. This has also been described for mutants of Staphylococcus aureus and Serratia marcescens (Forsgren et al., 1971; Omenn \& Friedman, 1970; Wadström, 1973; Yoshikawa et al., 1974; Winkler \& Timmis, 1973). A common regulatory mechanism in the synthesis or release of these proteins has been assumed by most authors, but Altenbern (1975) obtained mutants of $S$. aureus hyperproducing enterotoxin B and alpha haemolysin by selecting for membrane mutations.

In contrast to strain PAKS- $I$, five of the mutants did not release alkaline phosphatase into the medium, and four of these strains did not release staphylolytic enzyme. Alkaline phosphatase is an envelope-associated (periplasmic) enzyme (Cheng, Ingram \& Costerton, I97I). Staphylolytic enzyme is probably also envelope-associated (B. Wretlind, unpublished data), but it is not known whether the proteases or lipase belong to this group of proteins or are actively excreted, i.e. truly extracellular. The inability to release wall-associated enzymes indicates that a mutation affecting the envelope structure or function is the basis for the observed changes in phenotypic properties in these five mutants. For the remaining strains there are no data indicating such mutations, and it seems reasonable to assume the existence of an altered common regulatory mechanism for extracellular enzymes. The selection procedure used in this study would probably favour pleiotropic mutations, since PAKS-I produced three proteases with different isoelectric points and substrate specificities, and mutants with loss of a single enzyme might still produce zones on milk agar plates and remain undiscovered. It might be possible to find elastase-negative mutants with unchanged production of other extracellular enzymes by selection on elastin agar plates. However, such plates have a very low sensitivity and require a prolonged incubation which make them unsuitable for such experiments. The single mutant selected for loss of lecithinase (PAKs-3I) showed pleiotropic changes, and it is apparently easier to isolate such mutants than mutants with loss of a single enzyme.

Some of the protein A-deficient mutants of $S$. aureus described by Forsgren et al. (I97I) showed changes in the phage typing pattern and fermentation of mannitol. However, all PAKS-I mutants showed identical biochemical reactions, and phage type and serotype were essentially unchanged except for PAKS-20.

The genetic information for the synthesis of extracellular enzymes in $P$. aeruginosa might be located on plasmids as described for haemolysin and enterotoxin of Escherichia coli (So et al., 1975). Attempts to eliminate the extracellular protease activity by various curing procedures were unsuccessful, and analysis of DNA by ultracentrifugation in sucrose density gradients failed to reveal plasmid DNA in strain PAKS-I (L. Hedén and B. Wretlind, unpublished data). The phenotypic variability of the protease-deficient mutants suggests that more than one locus may be involved, and genetic mapping of protease-deficient mutants of $P$. aeruginosa strain PAO have shown at least three chromosomal loci (B. Wretlind, unpublished data). 
We would like to thank Drs C. J. Smyth and L. Hedén for stimulating discussion and Ms K. Jäderberg, Ms K. Karlsson, and Ms M. Kjellgren for expert technical assistance. This work was supported by a grant from the Research Institute of the Swedish National Defence.

\section{REFERENCES}

AltenbERN, R. A. (1975). Membrane mutations and production of enterotoxin $B$ and alpha hemolysin in Staphylococcus aureus. Canadian Journal of Microbiology 21, 275-280.

ARvidson, S., Holme, T. \& WADsTröm, T. (197I). Influence of cultivation conditions on the production of extracellular proteins by Staphylococcus aureus. Acta pathologica et microbiologica scandinavica B79, 399-405.

Burke, M. E. \& Pattee, P. A. (1967). Purification and characterization of a staphylolytic enzyme from Pseudomonas aeruginosa. Journal of Bacteriology 93, 860-866.

Cheng, K.-J., Ingram, J. M. \& Costerton, J. W. (I97I). Interactions of alkaline phosphatase and the cell wall of Pseudomonas aeruginosa. Journal of Bacteriology 107, 325-336.

DAVIS, B. D. \& MingIOLI, E. S. (1950). Mutants of Escherichia coli requiring methionine or vitamin $B_{12}$. Journal of Bacteriology 60, $17-28$.

ErICsSON, H. M. \& SherRIS, J. C. (I97I). Antibiotic sensitivity testing. Report of an international collaborative study. Acta pathologica et microbiologica scandinavica B, Supplement 217.

Forsgren, A., Nordström, K., Philipson, L. \& SJöQuIST, J. (197I). Protein A mutants of Staphylococcus aureus. Journal of Bacteriology 107, 245250.

HaBS, I. (1957). Untersuchungen über die O-Antigene von Pseudomonas aeruginosa. Zeitschrift für Hygiene und Infektionskrankheiten 144, 218-228.

Holloway, B. W. (I975). Genetic organization of Pseudomonas. In Genetics and Biochemistry of Pseudomonas, pp. 133-I6I. Edited by P. H. Clarke and M. H. Richmond. London: John Wiley.

Hugh, R. \& GILARdi, G. L. (1974). Pseudomonas. In Manual of Clinical Microbiology, 2nd edn, pp. 250-269. Edited by E. H. Lennette, E. H. Spaulding and J. P. Truant. Washington, D.C.: American Society for Microbiology.

Kawaharajo, K., Homma, J. Y., Aoyama, Y. \& MoriHaRA, K. (1975). In vivo studies on protease and elastase from Pseudomonas aeruginosa. Japanese Journal of Experimental Medicine 45, 89-100.

Kreger, A. S. \& Griffin, O. K. (1974). Physicochemical fractionation of extracellular corneadamaging proteases of Pseudomonas aeruginosa. Infection and Immunity 9, 828-834.

KunITZ, M. (I946/1947). Crystalline soybean trypsin inhibitor. II. General properties. Journal of General Physiology 30, 291-310.

LIU, P. V. (I964). Factors that influence toxigenicity of Pseudomonas aeruginosa. Journal of Bacteriology 88, I 42 I-1427.

LIU, P. V. (1974). Extracellular toxins of Pseudomonas aeruginosa. Journal of Infectious Diseases r3o Supplement, S94-S99.
Maliwan, N., Hess, A. R., Grieble, H. G. \& BIRD, T. J. (I974). Curing of carbenicillinase mediated resistance in Pseudomonas aeruginosa. In Progress in Chemotherapy, vol. I, pp. 186-192. Edited by G. K. Daikos. Athens: Hellenic Society of Chemotherapy.

Meynell, C. G. \& Meynell, E. (I970). Genetic technique. In Theory and Practice in Experimental Bacteriology, 2nd edn, pp. 256-294. London: Cambridge University Press.

MORIHARA, K. (1964). Production of elastase and proteinase by Pseudomonas aeruginosa. Journal of Bacteriology 88, 745-757.

Mull, J. D. \& Callahan, W. S. (I965). The role of the elastase of Pseudomonas aeruginosa in experimental infection. Experimental and Molecular Pathology 4, 567-575.

OMENN, G. S. \& FRIEDMAN, J. (1970). Isolation of mutants of Staphylococcus aureus lacking extracellular nuclease activity. Journal of Bacteriology IOI, 92I-924.

Praglin, J., Curtiss, A. C., Longhenry, D. K. \& MCKIE, JR, J. E. (I975). Autobac I-A 3-hours, automated antimicrobial susceptibility system. I. System description. In Automation in Microbiology and Immunology, pp. 197-208. Edited by C.-G. Hedén and T. Illéni. New York: John Wiley.

Rudin, L. \& v. Hofsten, B. (1974). Mutations in Arthrobacter affecting the formation of extracellular protease. Acta pathologica et microbiologica scandinavica $\mathrm{B82}, 657-666$.

SJöBERG, L. \& LiNDBERG, A. A. (1968). Phage typing of Pseudomonas aeruginosa. Acta pathologica et microbiologica scandinavica 74, 6I-68.

So, M., Crandall, J. F., Crosa, J. H. \& Falkow, S. (1975). Extrachromosomal determinants which contribute to bacterial pathogenicity. In Microbiology - 1974, pp. 16-26. Edited by D. Schlessinger. Washington, D.C.: American Society for Microbiology.

Staeudinger, M., v. Diemling, O., Grossarth, C. \& WiEnKER, T. (1973). Esterase. VIII. Histochemische, elektrophoretische und quantitative Untersuchungen zum Einfluss von Phenobarbital auf die Leberesterase der Maus. Histochemie 34, I07-I 16.

TORRIANI, A. (1968). Alkaline phosphatase of Escherichia coli. Methods in Enzymology 12B, 212-218.

VeRA, H. D. \& Dumoff, M. (1974). Culture media. In Manual of Clinical Microbiology, 2nd edn, pp. 88I-929. Edited by E. H. Lennette, E. H. Spaulding and J.P. Truant. Washington, D.C.: American Society for Microbiology.

WADSTRöM, T. (1973). Bacteriolytic enzymes from staphylococci. In Staphylococci and Staphylococcal Infections, pp. 397-405. Edited by J. Jeljaszewicz. Basel: Karger. 
WinkLer, U. \& Trmmis, K. (1973). Pleiotropic mutations in Serratia marcescens which increase the synthesis of certain exocellular proteins and the rate of spontaneous prophage induction. Molecular and General Genetics 124, 197-206.

WretLIND, B. \& WADSTRöM, T. (I977). Purification and properties of a protease with elastase activity from Pseudomonas aeruginosa. Journal of General Microbiology 103, 319-327.
Wretlind, B., Hedén, L., SJöberg, L. \& WADSTRÖM, T. (I973). Production of enzymes and toxins by hospital strains of Pseudomonas aeruginosa in relation to serotype and phage-typing pattern. Journal of Medical Microbiology 6, $9 \mathrm{I}-\mathrm{IOO}$. Yoshikawa, M., Matsuda, F., Naka, M., MuroFushi, E. \& Tsunematsu, Y. (1974). Pleiotropic alteration of activities of several toxins and enzymes in mutants of Staphylococcus aureus. Journal of Bacteriology 119, I I 7-122. 